\title{
PERFORMANSI PERTUMBUHAN IKAN BANDENG DENGAN PEMBERIAN PAKAN TEPUNG BIOFLOK YANG DISUPLEMENTASI ASAM AMINO ESENSIAL
}

\author{
Usman", Enang Harris"*), Dedi Jusadi"*), Eddy Supriyono"*), dan \\ Munti Yuhana"*i \\ *) Balai Penelitian dan Pengembangan Budidaya Air Payau \\ Jl. Makmur Dg. Sitakka No. 129, Maros 90512, Sulawesi Selatan \\ E-mail: siganus007@yahoo.com \\ **) Fakultas Perikanan dan Ilmu Kelautan, Institut Pertanian Bogor \\ Jl. Rasamala, Kampus IPB Darmaga, Bogor 16680
}

(Naskah diterima: 26 September 2013; Disetujui publikasi: 23 Mei 2014)

\begin{abstract}
ABSTRAK
Bioflok merupakan campuran heterogen dari mikroba, partikel, koloid, polimer organik, kation yang saling berintegrasi dan memiliki kandungan nutrisi yang dapat dimanfaatkan oleh ikan bagi pertumbuhannya. Namun beberapa kandungan asam amino esensial (AAE) tepung bioflok seperti histidine, lysine, dan methionine masih defisiensi untuk ikan. Oleh karena itu, penelitian ini bertujuan untuk menganalisis pemanfaatan tepung bioflok yang disuplementasi beberapa asam amino esensial sebagai pakan ikan bandeng. Ikan uji yang digunakan adalah yuwana bandeng berukuran rata-rata $18,4 \mathrm{~g}$ yang dipelihara dalam bak serat kaca bervolume $250 \mathrm{~L}$ dengan kepadatan awal 15 ekor/ bak, selama 60 hari. Perlakuan yang dicobakan adalah jenis pakan berupa: (A) tepung bioflok + asam amino esensial (histidine, lysine, dan methionine), (B) tepung bioflok, dan (C) pakan komersil, masing-masing 3 ulangan yang didisain dengan rancangan acak lengkap. Hasil penelitian menunjukkan bahwa nilai kecernaan dan konsumsi pakan harian kedua pakan uji bioflok lebih rendah daripada pakan komersil. Laju pertumbuhan ikan, efisiensi pakan, efisiensi protein, retensi protein, retensi lemak, dan retensi methionine berbeda nyata $(P<0,05)$ di antara perlakuan dan tertinggi terjadi pada ikan yang diberi pakan komersil diikuti berturut-turut pakan tepung bioflok + AAE dan terendah pakan tepung bioflok. Laju eskresi total ammonia nitrogen pada ikan yang diberi pakan tepung bioflok + AAE cenderung memiliki nilai yang lebih rendah daripada ikan yang diberi pakan tepung bioflok saja dan pakan komersil. Penambahan asam amino esensial (histidine, lysine, dan methionine) dalam tepung bioflok mampu memperbaiki pemanfaatan protein bioflok untuk pertumbuhan ikan bandeng.
\end{abstract}

KATA KUNCl: pertumbuhan, bandeng, tepung bioflok, asam amino esensial

ABSTRACT: Milkfish growth performance fed biofloc meal with amino acid essential supplementation. By: Usman, Enang Harris, Dedi Jusadi, Eddy Supriyono, dan Munti Yuhana

Biofloc is an integrated heterogeneous mixture of micro-organisms, particles, colloids, organic polymers and cation, which have nutritional contents for fish growth. However, the biofloc contains several essential amino acid (EAA) deficiency for fish such as histidine, lysine, and methionine. Therefor, this research aimed to analyse utilization of biolfoc meal with essential amino acid supplementation as feed for milkfish growout. The fish tested is milkfish juvenile with initial weight of $18.4 \mathrm{~g}$, reared in fibre glass tank with $250 \mathrm{~L}$ volume, and density of 15 fish/tank for 60 days. The treatments 
were done i.e. fish test fed: (A) biofloc meal + essential amino acid (histidine, lysine, and methionine), (B) biofloc meal, and (C) commercial feed, with three replicates for each treatment in completed randomized design. The results shown that the apparent digestibility coefficient and daily feed comsumption were lower $(P<0.05)$ for the both fed test of biofloc meal + EAA and biofloc meal compared to the commercial fed. Specific growth rate, feed efficiency, protein efficiency ratio, protein retention, lipid retention, and methionine retention significantly different $(P<0.05)$ among the treatments. The highest value for the variables were found in fish fed the commercial fed, followed by fish fed biofloc meal $+E A A$, and these lowest value in fish fed biofloc meal. The exretion rate of total ammonia nitrogen in fish fed biofloc meal + EAA tended lower than the fish fed only biofloc meal or fed commercial feed. The additional of the EAA in biofloc meal was able to improve utilization of biofloc protein for milkfish growth rate.

\section{KEYWORDS: growth performance, milkfish, biofloc meal, essential amino acid}

\section{PENDAHULUAN}

Saat ini, komponen pakan buatan untuk ikan didominasi oleh penggunaan tepung ikan sebagai sumber protein utama karena tepung ikan memiliki kandungan nutrisi yang sangat sesuai dengan kebutuhan ikan budidaya, utamanya profil asam amino esensialnya. Namun demikian, jumlah kebutuhan tepung ikan dunia semakin meningkat karena tidak hanya digunakan untuk pakan ikan tetapi juga digunakan untuk pakan babi dan poultry (unggas), sementara di sisi lain produksi tepung ikan cenderung stabil akibat hasil penangkapan yang stagnan. Tingginya kebutuhan protein dalam pakan ikan memberikan konsekuensi proporsi tepung ikan dalam formulasi pakan dapat mencapai 10\%-50\%, tergantung spesies ikannya. Pada nilai konversi pakan sekitar 1,5, maka diperlukan sebanyak $0,15-0,75 \mathrm{~kg}$ tepung ikan atau setara dengan 0,6-3 kg ikan rucah/segar (kadar air 75\%) untuk memproduksi $1 \mathrm{~kg}$ ikan. Hal ini menyebabkan akuakultur yang berbasis pakan buatan dengan tepung ikan sebagai sumber protein utamanya tergolong kegiatan yang tidak menguntungkan secara ekologis. Oleh karena itu, perlu adanya alternatif sumber protein pakan yang memiliki performansi nilai nutrisi yang relatif setara dengan tepung ikan atau paling tidak dapat memenuhi kebutuhan ikan budidaya untuk tumbuh secara optimum.

Beberapa penelitian terakhir tentang nutrisi dan pakan ikan banyak difokuskan pada pencarian bahan baku sumber protein alternatif untuk menggantikan peran utama tepung ikan dalam pakan. Tepung bioflok merupakan salah satu bahan yang berpotensi dijadikan sebagai sumber protein alternatif untuk men- substitusi penggunaan tepung ikan, khususnya dalam pakan ikan herbivora-omnivora seperti ikan bandeng. Bioflok ini merupakan campuran heterogen dari mikroba (bakteri, plankton, fungi, protozoa, ciliata, nematoda), partikel, koloid, polimer organik, kation yang saling berintegrasi cukup baik dalam air untuk tetap bertahan dari agitasi (goncangan) air yang moderat (Jorand et al., 1995). Pemicu pembentukan bioflok adalah populasi bakteri heterotrof. Pada kepadatan bakteri heterotrof yang cukup tinggi dalam media akan memicu terbentuknya bioflok. Tepung bioflok ini mengandung nutrisi seperti protein (19\%$40,6 \%$ ), lemak (0,46\%-1 1,6\%), dan abu (7\%-38,5\%) yang cukup baik bagi ikan/udang budidaya (Tacon, 2000; Ekasari, 2008 \& Avnimelech, 2009).

Bioflok dapat ditumbuhkan langsung dalam media budidaya secara bersamaan dengan pemeliharaan ikan budidaya dengan memanfaatkan limbah total ammonia-nitrogen (TAN). Penumbuhan bioflok dapat juga dilakukan dalam bio-reaktor dengan mengatur kebutuhan nutrien bakteri heterotrof seperti rasio $\mathrm{C} / \mathrm{N}$ dalam media pada kondisi aerobik (Avnimelech, 1999; Montoya \& Velasco, 2000; Mclntosh, 2001). Bakteri heterotrof merupakan scavengeryang efisien terhadap nutrien dan selain dapat menggunakan total amonium terlarut dalam air untuk pertumbuhannya, bakteri ini juga dapat menggunakan sumber nitrogen lainnya seperti senyawa organik dari feses dan sisa pakan. Umumnya bahan organik tersebut didekomposisi dalam kondisi aerobik. Bakteri heterotrof memiliki kemampuan yang lebih cepat memanfaatkan bahan anorganik dan organik tersebut menjadi protein bakteri daripada oleh fitoplankton dan bakteri nit- 
rifikasi (Montoya \& Velasco, 2000; Brune et al., 2003; Ebeling et al., 2006), sehingga memungkinkan untuk diproduksi secara massal.

Salah satu komponen nutrisi yang sangat penting dalam tepung bioflok adalah kandungan asam amino esensialnya. Tepung bioflok dilaporkan memiliki kandungan asam amino esensial yang relatif bervariasi tergantung jenis mikroba penyusunnya. Kandungan asam amino histidine, lysine, dan methionine merupakan 3 jenis asam amino yang sangat rendah pada tepung bioflok (Tacon, 2000), khususnya dalam kaitan proporsi dengan kandungan asam esensial tubuh ikan bandeng (Usman et al., 2011). Asam amino esensial yang tidak seimbang akan menyebabkan tingkat pemanfaatan protein pakan menjadi rendah. Adanya satu atau beberapa asam amino esensial yang defisien dalam pakan akan menjadi faktor pembatas, sehingga asam amino yang berlebih akan mengalami proses deaminasi dalam proses metabolisme. Hal ini akan menyebabkan eskresi TAN ikan ke lingkungan budidaya menjadi tinggi. Salah satu upaya meningkatkan pemanfaatan protein tepung bioflok ini adalah mensuplementasi asam amino esensial yang defisien tersebut berdasarkan tingkat kebutuhan ikan budidaya. Beberapa peneliti melakukan suplementasi asam amino yang defisien berdasarkan profil asam amino tubuh ikan budidaya itu sendiri (Mambrini \& Guillaume, 2001). Penelitian ini bertujuan menganalisis pemanfaatan tepung bioflok yang disuplementasi asam amino histidine, lysine dan methionine sebagai makanan bagi pertumbuhan yuwana ikan bandeng.

\section{BAHAN DAN METODE}

\section{Tepung Bioflok}

Bioflok ditumbuhkan di dalam media budidaya ikan bandeng yang dipelihara menggunakan dua bak beton berukuran 2,0 $\mathrm{m} \times 1,50$ $\mathrm{m} \times 1,2 \mathrm{~m}$ dengan pergantian air yang minim (hanya mengganti air yang hilang saat penyiponan bioflok yang mengendap secara periodik). Ikan berukuran rata-rata $120 \mathrm{~g}$ ditebar sebanyak 75 ekor/bak. Ikan tersebut diberi pakan komersil dengan kadar protein $26 \%$, lemak 6\%, dan energi total $4.194 \mathrm{kkal} / \mathrm{kg}$ sebanyak 3\%-4\% dari biomassa per hari pada pagi, siang, dan sore hari. Setelah pemberian pakan pada pagi dan sore hari, ke dalam media pemeliharaan tersebut diberi C-organik (molase) sebanyak $82 \%$ dari pakan harian
(Usman et al., 2010). Pada awal pemeliharaan, juga diinokulasi bakteri komersil (Bacillus sp.) sebanyak $1 \times 10^{6} \mathrm{cfu} / \mathrm{mL}$ untuk menginisiasi pertumbuhan bakteri menguntungkan dalam pembentukan bioflok (Usman et al., 2011). Sistem aerasi diatur sedemikian rupa sehingga bahan organik dapat tersuspensi dalam media pemeliharaan dan kadar oksigen terlarut $>3$ $\mathrm{mg} / \mathrm{L}$. Setelah bioflok tumbuh dengan baik, maka dilakukan pemanenan dengan penyaringan menggunakan plankton net ukuran lubang $45 \mathrm{~mm}$, lalu dikeringkan dalam oven pada suhu $60^{\circ} \mathrm{C}$, kemudian ditepungkan untuk dianalisis dan bahan pakan.

\section{Pakan Uji}

Tiga jenis pakan uji yang digunakan yaitu: (A) tepung bioflok yang disuplementasi dengan asam amino esensial (AAE) histidine, lysine, dan methionine, (B) tepung bioflok tanpa suplementasi asam amino, dan (C) pakan komersil (Tabel 1). Suplementasi asam amino tersebut didasarkan atas profil asam amino bioflok dan profil asam amino tubuh ikan bandeng (Tabel 2).

\section{Pemeliharaan Ikan}

Pemeliharaan ikan bandeng untuk pengamatan pertumbuhan dilakukan dalam sembilan bak fibre masing-masing berukuran $80 \mathrm{~cm} x$ $80 \mathrm{~cm} \times 60 \mathrm{~cm}$ yang diisi air bersalinitas 28-30 ppt masing-masing sebanyak $250 \mathrm{~L}$. Ikan uji berukuran rata-rata $18,4 \mathrm{~g}$ dimasukkan ke dalam sembilan bak dengan kepadatan masingmasing 15 ekor/bak. Ikan tersebut diberi pakan uji pada pagi, siang, dan sore hari secara satiasi selama 60 hari. Sisa pakan yang tidak termakan disipon dan dikeringkan. Untuk mempertahankan mutu air agar tetap baik, maka dilakukan pergantian air sekitar 50\%/hari. Selama penelitian, nilai kisaran media budidaya untuk salinitas antara $28-30 \mathrm{ppt}$; suhu air $27,5^{\circ} \mathrm{C}$ $31,0^{\circ} \mathrm{C}$; oksigen terlarut 4,5-5,6 mg/L; $\mathrm{pH} 7,6$ 8,1 ; TAN 0,025-0,347 mg/L; dan nitrit 0,016$0,08 \mathrm{mg} / \mathrm{L}$.

\section{Perhitungan Respons Pertumbuhan dan Pemanfaatan Pakan Uji}

Penilaian tingkat pemanfaatan pakan uji oleh yuwana ikan bandeng didasarkan atas beberapa parameter seperti:

Laju pertumbuhan spesifik (SGR) ikan dengan formula sebagai berikut (Schulz et al., 2005): 
Tabel 1. Komposisi bahan dan proksimat pakan uji (\% bobot kering)

Table 1. Ingredient composition and proximate analysis of the experimental diets (\% dry matter)

\begin{tabular}{|c|c|c|c|}
\hline \multirow{2}{*}{$\begin{array}{l}\text { Bahan } \\
\text { Ingredients }\end{array}$} & \multicolumn{3}{|c|}{ Pakan uji (Test diets) } \\
\hline & $\begin{array}{l}\text { Tepung bioflok + AAE") } \\
\left.\text { Biofloc meal }+E A A^{*}\right)\end{array}$ & $\begin{array}{l}\text { Tepung bioflok } \\
\text { Biofloc meal }\end{array}$ & $\begin{array}{l}\text { Pakan komersil } \\
\text { Commercial diet }\end{array}$ \\
\hline Tepung bioflok (Biofloc meal) & 98.68 & 99.75 & \\
\hline Histidine & 0.385 & - & \\
\hline Lysine & 0.477 & - & \\
\hline Methionine & 0.210 & - & \\
\hline Vitamin premix & 0.25 & 0.25 & \\
\hline \multicolumn{4}{|c|}{ Analisis proksimat (Proximate analysis): } \\
\hline Prote in & 30.2 & 29.7 & 33.1 \\
\hline Lemak (Lipid) & 2.86 & 2.93 & 6.1 \\
\hline Serat kasar (Crude fibre) & 3.0 & 3.2 & 3.4 \\
\hline Abu (Ash) & 24.6 & 25.2 & 12.4 \\
\hline $\begin{array}{l}\text { Energi total }(\mathrm{kkal} / \mathrm{kg}) \\
\text { Total energy }(\mathrm{kcal} . / \mathrm{kg})\end{array}$ & 3,588 & 3,553 & 4,292 \\
\hline
\end{tabular}

AAE = Asam amonio esensial; $E A A=$ Essential amino acid

**) Vitamin premix (dalam $1 \mathrm{~kg}$ pakan/in $1 \mathrm{~kg}$ feed): Vit. A $3000 \mathrm{IU}$; Vit. D $500 \mathrm{IU}$; Vit. E $2 \mathrm{IU}$; Vit. K $0.5 \mathrm{mg}$; Vit. $B_{1} 0.5 \mathrm{mg}$; Vit. $B_{2} 1.25 \mathrm{mg}$; Vit. $B_{6} 0.125 \mathrm{mg}$; Vit. $B_{12} 3 \mathrm{mg}$; Vit. C $6.25 \mathrm{mg}$; Calcium D-Pentathenate 1.5 $\mathrm{mg}$; Niacin $10 \mathrm{mg}$, dan (and) Cholin chloride $2.5 \mathrm{mg}$

Tabel 2. Komposisi AAE pakan uji dan tubuh ikan bandeng (\% protein) serta rasio AAE antara pakan dan tubuh ikan (\%)

Table 2. EAA composition of test diets and whole body of milkfish (\% protein) as well as EAA rasio of test diets and milkfish whole body

\begin{tabular}{|c|c|c|c|c|c|c|c|}
\hline \multirow[b]{2}{*}{$\begin{array}{l}\text { Jenis AAE } \\
\text { EAA kinds }\end{array}$} & \multicolumn{3}{|c|}{$\begin{array}{l}\text { Pakan uji } \\
\text { Test diets }\end{array}$} & \multirow{2}{*}{$\begin{array}{c}\text { Tubuh } \\
\text { ikan } \\
\text { bandeng } \\
\text { Milkfish } \\
\text { whole } \\
\text { body }\end{array}$} & \multicolumn{3}{|c|}{$\begin{array}{l}\text { Rasio AAE pakan dan tubuh ikan } \\
\text { EAA ratio of diets and milkfish } \\
\text { whole body (\%) }\end{array}$} \\
\hline & $\begin{array}{c}\text { Tep. } \\
\text { bioflok + } \\
\text { AAE } \\
\text { Biofloc } \\
\text { meal + } \\
\text { EAA }\end{array}$ & $\begin{array}{l}\text { Tep. } \\
\text { bioflok } \\
\text { Biofloc } \\
\text { meal }\end{array}$ & $\begin{array}{c}\text { Pakan } \\
\text { komersil } \\
\text { Commercial } \\
\text { diet }\end{array}$ & & $\begin{array}{c}\text { Tep. } \\
\text { bioflok + } \\
\text { AAE } \\
\text { Biofloc } \\
\text { meal + } \\
\text { EAA }\end{array}$ & $\begin{array}{c}\text { Tep. } \\
\text { bioflok } \\
\text { Biofloc } \\
\text { meal }\end{array}$ & $\begin{array}{c}\text { Pakan } \\
\text { komersil } \\
\text { Commercial } \\
\text { diet }\end{array}$ \\
\hline Arginine & 4.37 & 4.55 & 8.31 & 7.50 & 58.27 & 60.67 & 110.80 \\
\hline Histidine & 3.15 & 1.89 & 3.29 & 4.89 & 64.42 & 38.65 & 67.28 \\
\hline I-leucine & 3.18 & 3.16 & 5.71 & 3.93 & 80.92 & 80.41 & 145.29 \\
\hline Leucine & 4.74 & 4.75 & 5.41 & 7.33 & 64.67 & 64.80 & 73.81 \\
\hline Lysine & 4.64 & 3.10 & 5.32 & 7.92 & 58.59 & 39.14 & 67.17 \\
\hline Methionine & 2.52 & 1.58 & 4.02 & 3.72 & 67.74 & 42.47 & 108.06 \\
\hline Phenylalanine & 3.54 & 3.64 & 6.10 & 4.24 & 83.49 & 85.85 & 143.87 \\
\hline Threonine & 4.70 & 4.78 & 3.93 & 4.91 & 95.72 & 97.35 & 80.04 \\
\hline Valine & 5.10 & 5.05 & 2.99 & 4.55 & 112.10 & 110.99 & 65.71 \\
\hline
\end{tabular}




$$
\operatorname{SGR}(\% / \text { hari })=\frac{\ln W e-\ln W s}{d} \times 100 \%
$$

di mana:

In adalah logaritma alamiah, We and Ws berturutturut adalah bobot ikan pada akhir dan awal penelitian, dan d adalah jumlah hari pemeliharaan

Tingkat konsumsi pakan harian dihitung berdasarkan formula (Ozorio et al., 2009):

$$
P=\frac{T \times 100}{(\text { Bobot akhir }+ \text { Bobot awal) } / 2 \times d}
$$

di mana:

$\mathrm{P}=$ Konsumsi pakan harian (\%)

$\mathrm{T}=$ Total konsumsi pakan $(\mathrm{g})$

$\mathrm{d}=$ Lama pemeliharaan (hari)

Efisiensi pakan $=$ Pertambahan bobot biomassa (bobot basah) / Bobot konsumsi pakan (bobot kering) (Takeuchi, 1988)

Rasio efisiensi protein $=$ Pertambahan bobot ikan (g) / Jumlah protein yang dimakan (g) (Hardy, 1989)

Sintasan (\%) = (Jumlah ikan akhir penelitian / Jumlah ikan awal penelitian) $\times 100 \%$.

Retensi nutrien (protein, lemak, histidine, lysine, dan methionine) $(\%)=100 \times$ Pertambahan nutrien $(\mathrm{g}) /$ Jumlah konsumsi nutrien (g)\} (Takeuchi, 1988)

\section{Pengukuran TAN Plasma Darah Ikan}

Setelah pengamatan pertumbuhan ikan (60 hari pemeliharaan), dua ekor ikan dari setiap bak percobaan diambil darahnya sesaat sebelum pemberian pakan dan setelah lima jam pemberian pakan. Untuk mencegah stres selama pengambilan darah, ikan dibius menggunakan minyak cengkeh sebanyak $20 \mathrm{mg} / \mathrm{L}$. Sampel darah sebanyak $0,5 \mathrm{~mL}$ diambil menggunakan spuit (syringe) pada bagian pembuluh darah di atas pangkal ekor ikan dan dimasukkan ke dalam eppendorf. Pemisahan plasma dari sel darah dilakukan dengan sentrifuse berkecepatan $7.500 \mathrm{rpm}$ selama sepuluh menit pada suhu $5^{\circ} \mathrm{C}$ (Schram et al., 2010), untuk selanjutnya dianalisis kadar TAN menggunakan spektrofotometer berdasarkan APHA (1995).

\section{Pengukuran Eskresi TAN Ikan}

Ikan uji yang digunakan adalah yuwana ikan bandeng dengan kisaran bobot 22-36 g/ekor dari kegiatan pembesaran sebelumnya. Ikan tersebut terlebih dahulu dipuasakan selama 36 jam, lalu diberi pakan uji kembali sebanyak $1,5 \%$ dari biomassa, dan sisa pakan yang tidak termakan diambil. Pengukuran eksresi TAN dilakukan dengan menggunakan 10 bak fibre gelas berukuran $60 \mathrm{~cm} \times 40 \mathrm{~cm} \times 50 \mathrm{~cm}$ yang diisi air laut bersalinitas 30 ppt sebanyak $60 \mathrm{~L}$. Sembilan bak diisi ikan uji sebanyak 3-4 ekor/ bak dengan biomassa sekitar $100 \mathrm{~g} / \mathrm{bak}$. Selain itu, satu bak diisi air yang sama tanpa ikan sebagai blanko. Selama pengukuran TAN, tidak ada sirkulasi air dan aerasi. Untuk menghindari lepasnya TAN dalam media pemeliharaan, bak tersebut ditutup dengan styrofoam. Pengambilan sampel air untuk pengukuran TAN dilakukan sesaat setelah ikan diberi pakan (jam ke-0), dan pengambilan berikutnya dilakukan pada jam ke-5. Pengukuran TAN air dilakukan berdasarkan pada APHA (1995), dan Iaju eskresi TAN dihitung berdasarkan formula berikut (De Carvalho et al., 2010):

$$
X=\frac{\left(\mathrm{NH}_{3}-\mathrm{N}\right) \mathrm{t}_{\mathrm{i}}-\left(\mathrm{NH}_{3}-\mathrm{N}\right) \mathrm{t}_{0} \times \mathrm{V}}{\mathrm{g} \times \mathrm{t}}
$$

di mana:

$\mathrm{X}=$ Ekskresi $\mathrm{NH}_{3}-\mathrm{N}$ (mg/g tubuh/jam)

$\left(\mathrm{NH}_{3}-\mathrm{N}\right) \mathrm{t}_{0}=$ Konsentrasi amonia pada awal pengamatan ( $\mathrm{mg} / \mathrm{L})$

$\left(\mathrm{NH}_{3}-\mathrm{N}\right) \mathrm{t}_{\mathrm{i}}=$ Konsentrasi amonia pada akhir pengamatan $(\mathrm{mg} / \mathrm{L})$

$\mathrm{V}=$ Volume air dalam wadah (L)

$\mathrm{g}=$ Bobot ikan $(\mathrm{g})$

$\mathrm{t}=$ Lama pengambilan sampel (jam)

\section{Pengukuran Kecernaan Pakan}

Pengamatan tingkat kecernaan pakan uji dilakukan dengan menambahkan kromium oksida $\left(\mathrm{Cr}_{2} \mathrm{O}_{3}\right)$ sebanyak 0,75\% dalam pakan uji (Takeuchi, 1988). Pakan komersil ditepung ulang, lalu ditambahkan juga $0,75 \%$ kromium oksida sebagai indikator kecernaan dan dicetak seperti pakan tepung bioflok. Wadah peliharaan ikan berupa tanki conical fibre glass bervolume $200 \mathrm{~L}$ yang dilengkapi dengan sistem aerasi dan pergantian air. Ikan bandeng berukuran 20-25 g ditebar dengan kepadatan 20 ekor/tanki. Ikan diberi pakan uji secara satiasi per hari dengan frekuensi dua kali sehari pada pagi dan sore hari. Beberapa saat setelah pemberian pakan, air dikeluarkan untuk membuang sisa pakan yang ada dengan membuka kran bagian bawah. Sebelum pengambilan feses, ikan diadaptasikan dengan pakan uji tersebut selama satu minggu, lalu pengumpulan feses dilakukan setiap jam untuk men- 
cegah terjadi leaching nutrien pada feses. Feses yang terkumpul secepatnya disimpan dalam freezer hingga cukup untuk analisis kemudian dikeringkan. Koefisien kecernaan bahan kering, protein, dan energi pakan uji dihitung dengan rumus (Takeuchi, 1988):

$$
\operatorname{ADC}(\%)=\left[1-\left[\frac{\mathrm{Md} \times \mathrm{Af}}{\mathrm{Mf} \times \mathrm{Ad}}\right]\right] \times 100
$$

di mana:

$\mathrm{ADC}=$ Apparent digestibility coefficient dari: bahan kering, protein, dan energi; Md dan Mf berturutturut adalah kandungan kromium dalam pakan dan feses, Ad dan Af berturut-turut adalah kadar nutrien dalam pakan dan feses

\section{Analisis Kimia dan Statistik}

Pada analisis proksimat pakan, ikan dan feses dari sampel yang representative dianalisis berdasarkan prosedur Takeuchi (1988). Kandungan energi total pakan berkrom dan feses diukur dengan menggunakan bomb-calorimeter. Kandungan kromium dalam sampel pakan dan feses dianalisis berdasarkan prosedur Takeuchi (1988). Komposisi asam amino pakan uji dan tubuh ikan bandeng dianalisis dengan menggunakan High Performance Liquid Chromatography (HPLC).

Peubah yang diamati berupa laju pertumbuhan ikan, tingkat konsumsi pakan, efisiensi pakan, rasio efisiensi protein, retensi nutrien (protein, lemak, histisine, lysine, methionine), komposisi kimia tubuh, dan kecernaan nutrien pakan dianalisis ragam dan dilanjutkan dengan uji nilai tengah BNT pada selang kepercayaan 95\% (Steel \& Torrie, 1995). Kandungan TAN plasma darah dan laju eskresi TAN dianalisis secara deskriptif.

\section{HASIL DAN BAHASAN}

\section{Kecernaan Pakan}

Pakan yang dikonsumsi oleh ikan terlebih dahulu akan mengalami proses pencernaan sebelum diserap masuk ke dalam peredaran darah. Semakin tinggi nilai kecernaan pakan, maka peluang pemanfaatan pakan tersebut untuk sumber energi dan pertumbuhan ikan semakin besar. Hasil pengukuran nilai kecernaan pakan uji disajikan pada Tabel 3. Pada tabel tersebut terlihat bahwa nilai kecernaan pakan, baik bahan kering, protein maupun energi pakan yang mengandung tepung bioflok lebih rendah dan berbeda nyata $(P<0,05)$ dibandingkan pakan komersil. Tepung bioflok ini tersusun oleh gabungan berbagai jenis komponen seperti bakteri, jamur, plankton, protozoa, ciliata, nematoda, koloid, polimer organik, dan kation yang didominasi oleh kelompok mikroba tersebut sehingga mirip single cell protein (SCP). Menurut Tacon \& Cooke (1980), salah satu penyebab rendahnya nilai kecernaan single cell protein pada ikan adalah tingginya kandungan asam nukleat dalam bahan tersebut. Selanjutnya Schneider et al. (2004) melaporkan bahwa SPC memiliki nilai kecernaan yang rendah dibandingkan sumber protein konvensional lainnya disebabkan oleh adanya dinding sel dan kandungan asam nukleat yang tinggi. Dinding sel SCP tersusun oleh heteropolisakarida kompleks dalam struktur karbohidrat-protein kompleks seperti mannaprotein dan glucan yang susah dicerna oleh ikan (Farkas, 1985 dalam Lee, 2002). Selain itu, tingkat kecernaan yang rendah ini juga dapat disebabkan oleh kandungan abu bioflok yang cukup tinggi (sekitar 25\% pada tepung bioflok dan hanya

Tabel 3. Koefisien kecernaan pakan uji (\%)

Table 3. Apparent digestibility coefficients of test diest (\%)

\begin{tabular}{lccc}
\hline \multirow{2}{*}{$\begin{array}{c}\text { Nutrien } \\
\text { Nutrients }\end{array}$} & \multicolumn{3}{c}{ Pakan uji (Test diets) } \\
\cline { 2 - 4 } & $\begin{array}{c}\text { Tep. bioflok + AAE } \\
\text { Biofloc meal + EAA }\end{array}$ & $\begin{array}{c}\text { Tep. bioflok } \\
\text { Biofloc meal }\end{array}$ & $\begin{array}{c}\text { Pakan komersil } \\
\text { Commercial diet }\end{array}$ \\
\hline Bahan kering (Dry matter) & $50.3 \pm 4.8^{\mathrm{a}}$ & $48.4 \pm 5.6^{\mathrm{a}}$ & $66.5 \pm 2.9^{\mathrm{b}}$ \\
Protein & $77.1 \pm 3.7^{\mathrm{a}}$ & $78.2 \pm 4.3^{\mathrm{a}}$ & $87.3 \pm 2.1^{\mathrm{b}}$ \\
Energi total (Total energy) & $62.1 \pm 5.4^{\mathrm{a}}$ & $61.8 \pm 4.9^{\mathrm{a}}$ & $73.2 \pm 3.6^{\mathrm{b}}$ \\
\hline
\end{tabular}

Nilai dalam baris yang sama diikuti oleh superscript yang sama menunjukkan tidak berbeda nyata ( $P>$ $0,05)$ (Means in the same row followed by the same superscript are not significantly different $(P>0.05)$ ) 
$12,4 \%$ pada pakan komersil). Menurut Lee (2002), kadar abu yang tinggi dalam bahan turut memberikan pengaruh negatif terhadap tingkat kecernaan nutrien bahan pakan. Bioflok ini merupakan campuran mikroorganisme dengan partikel, koloid, dan ion yang saling berikatan dalam air. Air laut (salinitas 25$30 \mathrm{ppt}$ ) yang digunakan dalam penumbuhan bioflok ini kaya ion seperti, $\mathrm{Cl}, \mathrm{K}^{+}, \mathrm{Na}^{+}, \mathrm{Ca}^{+}$, $\mathrm{Mg}^{+}$, dan lain-lain sehingga kandungan abu dalam tepung bioflok tersebut cukup tinggi. Kadar abu yang tinggi dalam bioflok ini juga dilaporkan oleh Tacon (2000) yaitu 22,9\%$38,5 \%$ bahan kering.

Setelah pemeliharaan selama 60 hari, didapatkan performansi pertumbuhan ikan bandeng dan pemanfaatan pakan uji seperti disajikan pada Tabel 4. Pada tabel tersebut terlihat bahwa laju pertumbuhan spesifik ikan, konsumsi pakan harian, efisiensi pakan, sintasan, rasio efisiensi pakan, retensi protein, dan retensi lemak terdapat perbedaan yang nyata $(P<0,05)$ di antara ketiga perlakuan. Nilai peubah tersebut tertinggi terjadi pada ikan yang diberi pakan komersil, diikuti pakan tepung bioflok yang disuplementasi asam amino esensial (AAE) dan terendah pada pakan tepung bioflok tanpa suplementasi AAE.
Laju pertumbuhan yang rendah pada ikan yang diberi pakan berupa tepung bioflok saja dan tepung bioflok + AAE disebabkan karena tingkat konsumsi pakan hariannya relatif rendah (1,16\%-1,27\%), sementara ikan yang diberi pakan komersil memiliki tingkat konsumsi pakan harian rata-rata 2,19\%. Rendahnya tingkat konsumsi pakan ini menyebabkan ekspresi potensi tumbuh ikan tidak dapat terjadi secara maksimum. Menurut Boujard (2001), tingkat konsumsi pakan harian pada ikan dipengaruhi oleh faktor nutrisi dan $p a-$ latability pakan, faktor lingkungan (air), dan faktor tingkah laku ikan. Kondisi kualitas air selama pemeliharaan ikan cukup optimum bagi pertumbuhan ikan, sehingga tampaknya penyebab utama rendahnya tingkat konsumsi pakan adalah faktor palatability pakan yang mempengaruhi appetite ikan terhadap pakan yang hanya mengandung tepung bioflok dan tepung bioflok+AAE. Penurunan konsumsi pakan harian juga terjadi pada ikan Oreochromis mossambicus ketika diberi pakan yang menggunakan single cell protein lebih dari $40 \%$ untuk menggantikan penggunaan tepung ikan (Davies \& Wareham, 1988). Selanjutnya dikatakan bahwa selain tingkat konsumsi pakan yang rendah, juga adanya

Tabel 4. Performansi pertumbuhan yuwana ikan bandeng yang diberi pakan uji

Table 4. Growth performances of juvenile milkfish fed test diets

\section{Variabel Variables}

Pakan uji (Test diets)

\begin{tabular}{|c|c|c|}
\hline $\begin{array}{l}\text { Tep. bioflok + AAE } \\
\text { Biofloc meal + EAA }\end{array}$ & $\begin{array}{l}\text { Tep. bioflok } \\
\text { Biofloc meal }\end{array}$ & $\begin{array}{l}\text { Pakan komersil } \\
\text { Commercial die }\end{array}$ \\
\hline
\end{tabular}

\begin{tabular}{lccc}
\hline Bobot awal (Initial weight) (g) & $18.3 \pm 0.3$ & $18.4 \pm 0.3$ & $18.5 \pm 0.4$ \\
$\begin{array}{l}\text { Bobot akhir (Final weight) (g) } \\
\text { Laju pertumbuhan spesifik (\%/hari) }\end{array}$ & $23.8 \pm 0.9$ & $22.4 \pm 0.8$ & $36.2 \pm 1.1$ \\
$\begin{array}{l}\text { Daily growth rate (\%/day) } \\
\text { Konsumsi pakan harian }\end{array}$ & $0.43 \pm 0.06^{\mathrm{b}}$ & $0.32 \pm 0.04^{\mathrm{a}}$ & $1.12 \pm 0.06^{\mathrm{c}}$ \\
$\begin{array}{l}\text { Daily feed consumption (\%) } \\
\text { Efisiensi pakan (Feed efficiency) }\end{array}$ & $1.27 \pm 0.09^{\mathrm{a}}$ & $1.16 \pm 0.06^{\mathrm{a}}$ & $2.19 \pm 0.03^{\mathrm{b}}$ \\
$\begin{array}{l}\text { Sintasan (Survival rate) (\%) } \\
\text { Rasio efisiensi protein }\end{array}$ & $86.7 \pm 6.7^{\mathrm{ab}}$ & $82.2 \pm 3.87^{\mathrm{a}}$ & $95.5 \pm 3.9^{\mathrm{b}}$ \\
$\begin{array}{l}\text { Protein efficiency ratio } \\
\text { Retensi protein }\end{array}$ & $0.93 \pm 0.11^{\mathrm{b}}$ & $0.68 \pm 0.11^{\mathrm{a}}$ & $1.43 \pm 0.06^{\mathrm{c}}$ \\
$\begin{array}{l}\text { Protein retention (\%) } \\
\text { Retensi lemak (Lipid retention) (\%) }\end{array}$ & $38.54 \pm 9.45^{\mathrm{a}}$ & $22.01 \pm 12.29^{\mathrm{a}}$ & $67.81 \pm 8.76^{\mathrm{b}}$ \\
\hline
\end{tabular}

Nilai dalam baris yang sama diikuti oleh superscript yang sama menunjukkan tidak berbeda nyata (P> $0,05)$ (Means in the same row followed by the same superscript are not significantly different $(P>0.05)$ ) 
defisiensi beberapa asam amino esensial dalam single cell protein, sehingga menyebabkan laju pertumbuhan ikan dan efisiensi pakan menjadi rendah. Pengaruh kandungan abu tepung bioflok yang tinggi terhadap rendahnya palatability dan efeknya terhadap pertumbuhan ikan saat ini belum diketahui.

Ikan yang diberi pakan tepung bioflok + AAE memiliki laju pertumbuhan yang lebih tinggi dibandingkan ikan yang hanya diberi pakan tepung bioflok. Hal ini menunjukkan bahwa penambahan asam amino esensial tersebut mampu memperbaiki pemanfaatan pakan bagi pertumbuhan ikan. Beberapa asam amino esensial dalam tepung bioflok mengalami defisiensi bila dibandingkan profil asam amino tubuh ikan bandeng, utamanya histidine, lysine dan methionine. Penambahan asam amino tersebut dalam tepung bioflok (Gambar 1) mampu memberikan keseimbangan profil asam amino, sehingga pemanfaatan protein (asam amino) untuk pertumbuhan (sintesis protein tubuh) menjadi meningkat. Hal ini terlihat pada nilai efisiensi pakan, efisiensi protein dan retensi protein yang lebih tinggi pada ikan yang diberi pakan bioflok + AAE dibandingkan pada ikan yang hanya diberi pakan tepung bioflok. Nilai efisiensi protein dan retensi protein tertinggi terjadi pada ikan yang diberi pakan komersil. Hal ini disebabkan nilai perbandingan kandungan asam amino esensial dalam pakan komersil dengan tubuh ikan ratarata lebih tinggi (kecuali valine dan threonine) dibandingkan kedua pakan tepung bioflok yang diujikan. Selain itu, pakan komersil juga memiliki tingkat konsumsi pakan dan tingkat kecernaan protein yang tinggi daripada pakan tepung bioflok tersebut, sehingga cukup memberikan dampak baik terhadap pertumbuhan ikan bandeng.

Profil asam amino pakan sangat penting dalam kaitannya dengan sintesis protein untuk pertumbuhan ikan. Profil asam amino esensial pakan yang mirif profil asam amino tubuh ikan memiliki peluang pemanfaatan untuk pertumbuhan ikan yang lebih tinggi, terutama ketika terjadi kecukupan energi dari sumber non-protein (lemak dan karbohidrat). Penambahan asam amino yang defisien dalam tepung bioflok juga menyebabkan adanya kecenderungan peningkatan pada retensi histidine dan lysine (meskipun tidak berbeda nyata, $P>0,05)$ dan khususnya pada retensi methionine $(P<0,05)$ dalam tubuh ikan bandeng (Gambar 2). Hal ini menunjukkan bahwa penambahan asam amino histidine, lysine, dan methionine mampu memperbaiki kualitas asam amino tepung bioflok ini bagi pertumbuhan yuwana ikan bandeng.

Pada pengamatan kadar TAN plasma darah ikan, tampak bahwa sebelum pemberian pakan, rata-rata kadar TAN berkisar antara 19,43-21,27 $\mathrm{mg} / \mathrm{L}$ dan meningkat menjadi rata-rata antara 27,13-27,97 mg/L setelah pemberian pakan (Gambar 3). Peningkatan kadar TAN plasma darah setelah pemberian pakan menunjukkan

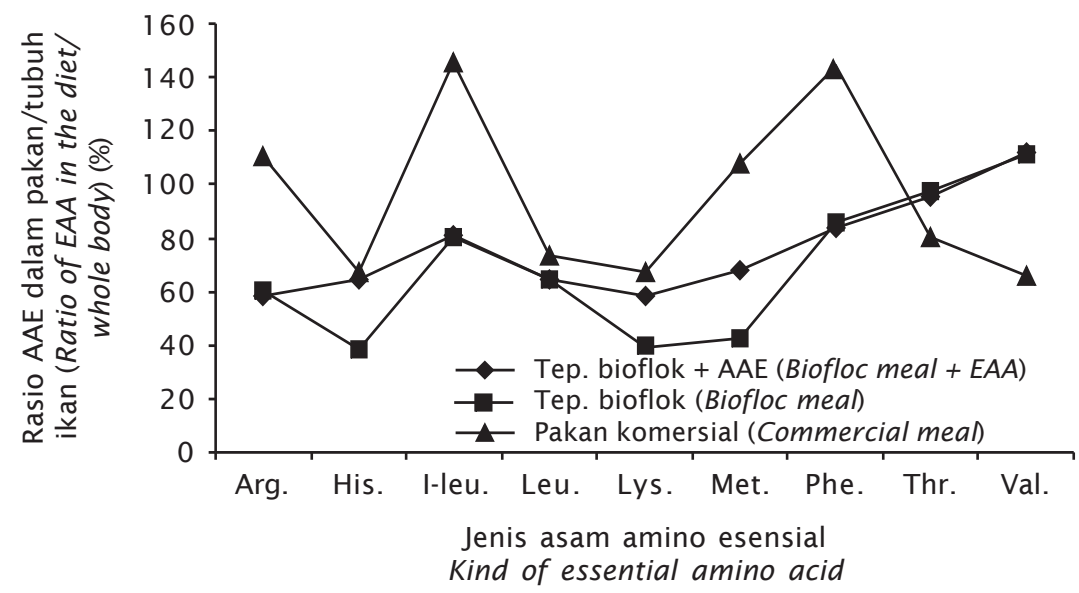

Gambar 1. Perbandingan kandungan asam amino esensial dalam pakan uji dan tubuh ikan bandeng (\%)

Figure 1. The comparison of essential amino acid in the test diet and the whole body of milkfish (\%) 


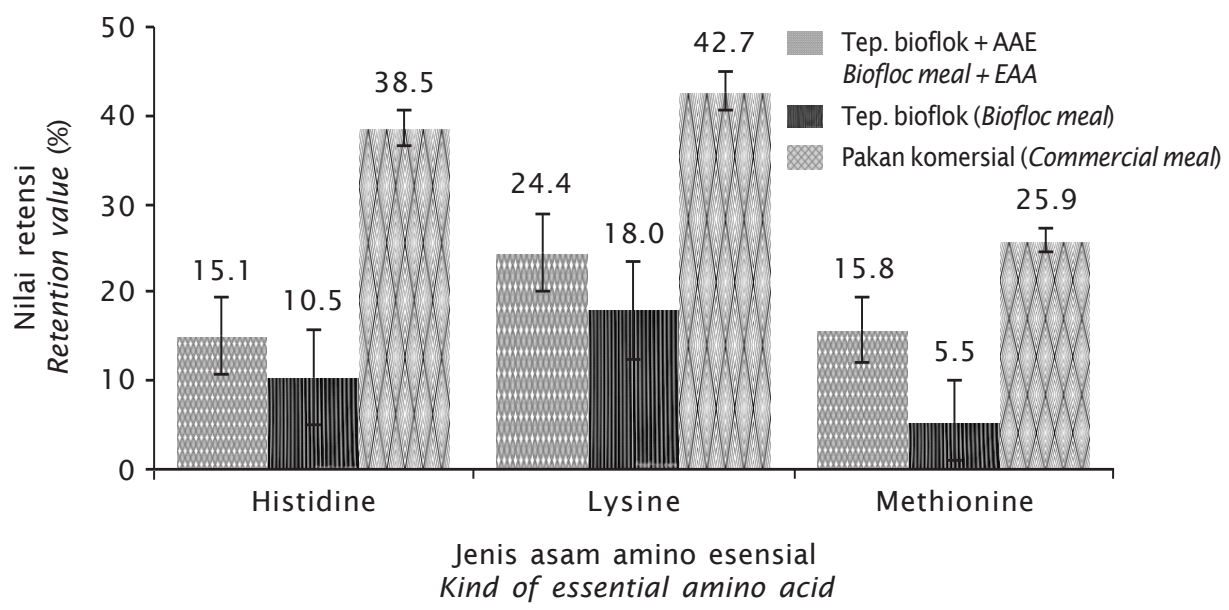

Gambar 2. Retensi asam amino histidine, lysine, dan methionine setelah pemberian pakan pada yuwana ikan bandeng

Figure 2. Retention of amino acid histidine, lysine, and methionine after fed test diets to milkfish juvenile

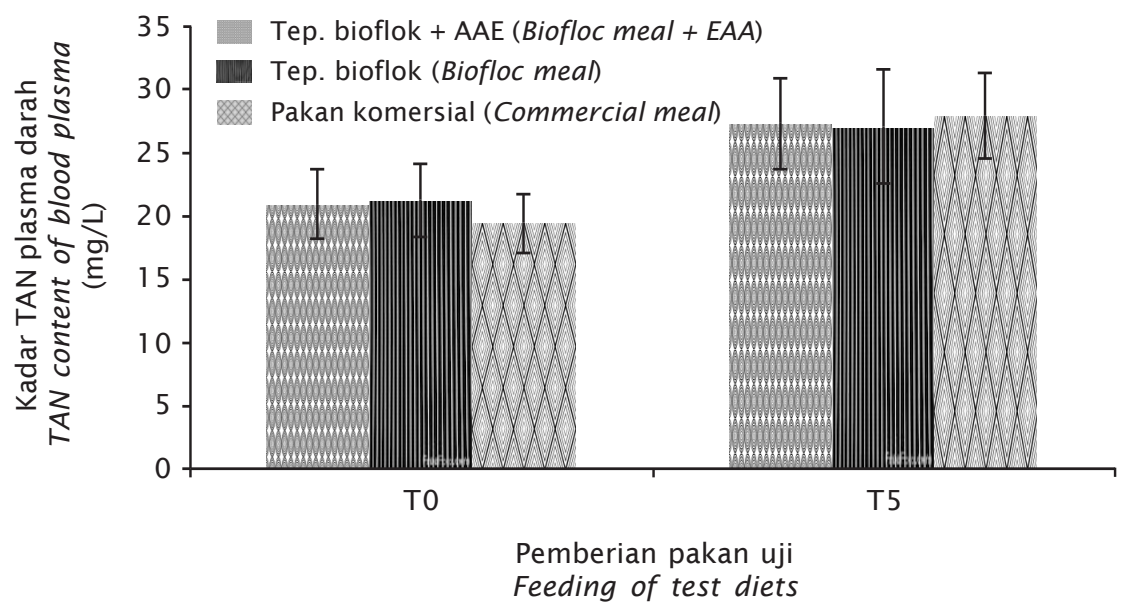

Gambar 3. Kandungan TAN dalam plasma darah ikan bandeng sebelum (T0) dan setelah (T5) pemberian pakan uji

Figure 3. TAN content of blood plasma of milkfish before (TO) and after (T5) feeding of test diets

terjadinya peningkatan proses deaminasi, sehingga sebagian asam amino dari pakan yang diserap tersebut diubah menjadi amonia. Kadar TAN plasma darah ikan baik yang diberi pakan tepung bioflok + AAE maupun yang hanya tepung bioflok memiliki nilai yang relatif sama, sedangkan ikan yang diberi pakan komersil memiliki nilai TAN plasma yang sedikit lebih tinggi meskipun juga tidak berbeda nyata $(P>0,05)($ Gambar 3).
TAN dalam darah ikan selanjutnya akan dieskresikan ke dalam air (media budidaya), sehingga salah satu indikator lain yang dapat digunakan untuk menilai tingkat pemanfaatan protein dan asam amino pakan pada ikan uji adalah mengukur laju eskresi TAN ikan setelah pemberian pakan. Pada pengamatan laju eskresi TAN (Gambar 4), didapatkan bahwa ikan yang diberi pakan tepung bioflok + AAE memiliki laju ekskresi TAN yang relatif lebih 


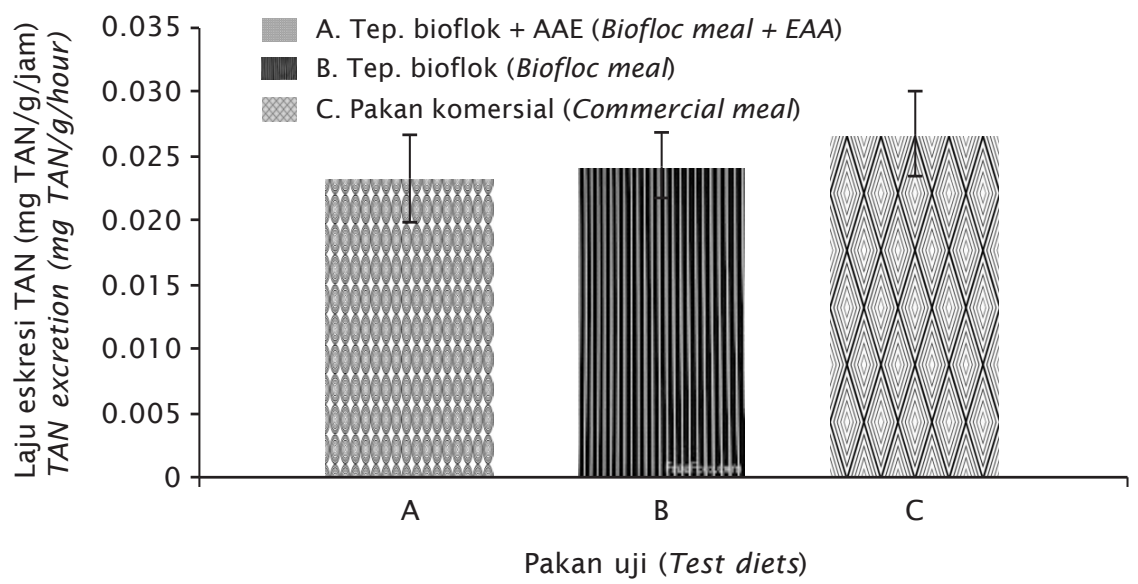

Gambar 4. Laju eskresi TAN ikan bandeng yang diberi pakan uji

Figure 4. TAN excretion of milkfish fed test diets

rendah, meskipun tidak berbeda nyata $(P>0,05)$ dibandingkan ikan yang diberi pakan tepung bioflok saja. Hal ini mendukung data tentang nilai efisiensi protein, retensi protein dan retensi asam amino pada pakan uji tersebut. Ikan uji yang diberi pakan komersil juga cenderung memiliki laju eskresi TAN yang lebih tinggi dibandingkan kedua pakan uji bioflok, hal ini disebabkan karena ikan yang diberi pakan komersil mengkonsumsi semua pakan uji yang diberikan (1,5\% bobot tubuh), sedangkan ikan yang diberi pakan uji bioflok + AAE dan bioflok saja hanya mengkonsumsi pakan sekitar $1 \%$ bobot tubuh saja.

Ikan uji yang diberi pakan bioflok + AAE dan bioflok saja memiliki komposisi proksimat tubuh yang relatif sama $(P>0,05)$ dan dengan ikan awal (Tabel 5). Namun ikan uji yang diberi pakan komersil memiliki kandungan protein dan abu yang lebih rendah, karena adanya peningkatan kandungan lemak yang cukup tinggi. Hal ini menunjukkan bahwa ikan yang diberi pakan komersil ini memiliki kelebihan konsumsi energi yang lebih banyak dari pada ikan yang diberi bioflok + AAE dan bioflok saja, sehingga terjadi proses lipogenesis yang lebih intensif.

\section{KESIMPULAN}

Berdasarkan hasil penelitian ini maka disimpulkan bahwa: Tepung bioflok memiliki nilai kecernaan, tingkat palatability, dan konsumsi yang rendah dibandingkan pakan komersil oleh ikan bandeng. Penambahan asam

Tabel 5. Komposisi proksimat tubuh ikan bandeng yang diberi pakan uji (\% bobot kering)

Table 5. Whole body proximate composition of milkfish fed test diet (\% dry weight)

\begin{tabular}{lcccc}
\hline \multirow{2}{*}{$\begin{array}{c}\text { Nutrien } \\
\text { Nutrients }\end{array}$} & $\begin{array}{c}\text { Ikan } \\
\text { awal }\end{array}$ & \multicolumn{3}{c}{ Akhir percobaan (The end of experiment) } \\
\cline { 3 - 5 } & Initial & Tep. bioflok + AAE & Tep. Bioflok & Pakan komersil \\
fish & Biofloc meal + EAA & Biofloc meal & Tommercial diet \\
\hline Protein kasar (Crude protein) & 65.8 & $66.6 \pm 1.1^{\mathrm{a}}$ & $66.3 \pm 1.2^{\mathrm{a}}$ & $63.4 \pm 1.1^{\mathrm{b}}$ \\
Lemak (Lipid) & 18.2 & $17.2 \pm 0.9^{\mathrm{a}}$ & $17.3 \pm 0.6^{\mathrm{a}}$ & $23.3 \pm 1.2^{\mathrm{b}}$ \\
Serat kasar (Crude fibre) & 1.3 & $0.8 \pm 0.3^{\mathrm{a}}$ & $0.9 \pm 0.4^{\mathrm{a}}$ & $0.7 \pm 0.1^{\mathrm{a}}$ \\
Abu (Ash) & 12 & $12.5 \pm 0.6^{\mathrm{a}}$ & $12.7 \pm 0.6^{\mathrm{a}}$ & $11.0 \pm 0.7^{\mathrm{b}}$ \\
BETN (NFE) & 2.6 & $2.9 \pm 0.8^{\mathrm{a}}$ & $2.8 \pm 0.6^{\mathrm{a}}$ & $1.6 \pm 0.6^{\mathrm{a}}$ \\
\hline
\end{tabular}

Nilai dalam baris yang sama diikuti oleh superscript yang sama menunjukkan tidak berbeda nyata ( $\mathrm{P}>$ $0,05)$ (Means in the same row followed by the same superscript are not significantly different $(P>0.05)$ ) 
amino esensial histidine, lysine, dan methionine dalam tepung bioflok mampu meningkatkan laju pertumbuhan ikan, efisiensi pakan, efisiensi protein, retensi protein, retensi methionine dan menekan laju eskresi TAN, tetapi tidak meningkatkan konsumsi pakan ikan bandeng. Ikan bandeng yang diberi pakan tepung bioflok baik yang disuplementasi AAE maupun tanpa suplementasi AAE memiliki performansi pertumbuhan yang lebih rendah daripada yang diberi pakan komersil.

\section{DAFTAR ACUAN}

APHA (American Public Health Association). 1995. Standard Methods for the Examination of Water and Waste Water, $19^{\text {th }}$ ed. American Public Health Association, Washington, DC, 1,082 pp.

Avnimelech, Y. 1999. Carbon/nitrogen ratio as a control element in aquaculture systems. Aquaculture, 176: 227-235.

Avnimelech, Y. 2009. Biofloc Technology. World Aquaculture Society, Louisiana, USA, 182 pp.

Boujard, T. 2001. Feeding behavior and regulation of food intake. In: Guillaume, J., Kaushik, S., Bergot, P., \& Metailler, P. (eds). Nutritional and Feeding of Fish and Crustaceans. Springer-Praxis Publishing, Chichester, UK, p. 19-25.

Brune, D.E., Schwartz, G., Eversole, A.G., Collier, J.A., \& Schwedler, T.E. 2003. Intensification of pond aquaculture and high rate photosynthetic systems. Aquaculture Engineering, 28: 65-86.

Davies, S.J. \& Wareham, H. 1988. A preliminary evaluation of an industrial single cell protein in practical diets for tilapia (Oreochromis mossarnbicus Peters). Aquaculture, 73:189-199.

De Carvalho, C.V.A., Bianchini, A., Tesser, M.B., \& Sampaio, L.A. 2010. The effect of protein levels on growth, postprandial excretion and tryptic activity of juvenile mullet, Mugil platanus (Gunther). Aquaculture Research, 41:511-518.

Ekasari, J. 2008. Biofloc technology: The effect different carbon source, salinity and the addition of probiotics on the primary nutritional value of the bioflocs (M.Sc thesis). Ghent. Ghent University, Belgium, 72 pp.

Ebeling, J.M., Timmons, M.B., \& Bisogni, J.J. 2006. Engineering analysis of the stoichiometry of photoautotrophic, autotrophic and heterotrophic removal of ammonia-nitrogen in aquaculture systems. Aquaculture, 257: 346-358.

Hardy, R.W. 1989. Diet preparation. In: Halver JE, editor. Fish Nutrition. Second Edition. Academic Press. San Diego, p. 476-549.

Jorand, F., Zartarian, F., Thomas, F., Block, J.C., Betteru, J.V., Villemin, G., Urbain, V., \& Manen, J. 1995. Chemical and structural $\left(2^{\text {nd }}\right)$ linkage between bacteria within activated-sludge flock. Water Res., 29 (7): 1,639-1,647.

Lee, S.M. 2002. Apparent digestibility coefficients of various feed ingredients for juvenile and grower rockfish (Sebastes schlegeli). Aquaculture, 207: 79-95.

Mambrini, M. \& Guillaume, J. 2001. Protein nutrition. In: Guillaume, J., Kaushik, S., Bergot, P. \& Metailler, P. (eds). Nutritional and Feeding of Fish and Crustaceans. SpringerPraxis Publishing, Chichester, UK, p. 81-110.

McIntoch, R.P. 2001. Ghangin paradigms in shrimp farming: V. Establishment of heterotrophic bacterial communities. Global Aquaculture Advocate, 4(1): 53-58.

Montoya, R. \& Velasco, M. 2000. Role of bacteria on nutritional and management strategies in aquaculture systems. Global Aquaculture Advocate, 3(2): 35-36.

Ozorio, R.O.A., Valente, L.M.P., Correia, S., Pousao-Ferreira, P., Damasceno-Oliveira, A., Escorcia, C., \& Oliva-Teles, A. 2009. Protein requirement for maintenance and maximum growth of two-banded seabream (Diplodus vulgaris) juveniles. Aquaculture Nutrition, 15: 85-93.

Schram, E., Roques, J.A.C., Abbink, W., Spanings, T., De Vries, P., Bierman, S., Van de Vis, H., \& Flik, G. 2010. The impact of elevated water ammonia concentration on physiology, growth and feed intake of African catfish (Clarias gariepinus). Aquaculture, 306: 108115.

Schulz, C., Knaus, U., Wirth, M., \& Rennert, B. 2005. Effect of varying dietary fatty acid propile on growth performance, fatty acid, body and tissue composition of juvenile pike perch (Sander lucioperca). Aquaculture Nutrition, 11: 403-413.

Schneider, O., Amirkolaie, A.K., Vera-Cartas, J., Eding, E.H., Schrama, J.W., \& Verretl, J.A.J. 2004. Digestibility, feces recovery and related carbon, nitrogen and phosphorus balances of five feed ingredients evaluated as fish meal alternative in Nile tilapia, Oreochromis niloticus. L. Aquaculture Re- 
search, 35: 1,370-1,379.

Steel, R.G.D. \& Torrie, J.H. 1995. Prinsip dan Prosedur Statistika. Alih bahasa: Bambang Sumantri. Gramedia Pusaka Utama, Jakarta, $748 \mathrm{hlm}$.

Takeuchi, T. 1988. Laboratory work-chemical evaluation of dietary nutrients. In: Watanabe, T. Editor. Fish Nutrition and Mariculture. Department of Aquatic Bioscience, University of Fisheries, Tokyo, p. 179-233.

Tacon, A.G.J. \& Cooke, D.J. 1980. Nutritional value of dietary nucleic acids to trout. Nutr. Reports Int., 22: 631-640.
Tacon, A.G.J. 2000. Shrimp feeds and feeding regime in zero exchange outdoor tanks. Global Aquaculture Advocate, 3(2): 15-16.

Usman, Palinggi, N.N., Harris, E., Jusadi, D., Supriyono, E., \& Yuhana, M. 2010 . Analisis tingkat kecernaan pakan dan limbah nitrogen $(\mathrm{N})$ budidaya ikan bandeng serta kebutuhan C-organik untuk penumbuhan bakteri heterotrof (bioflok). Jurnal Riset Akuakultur, 5(3): 481-490.

Usman, Harris, E., Jusadi, D., Supriyono, E., \& Yuhana, M. 2011. Penumbuhan bioflok dalam media budidaya ikan bandeng. Jurnal Riset Akuakultur, 6(1): 41-50. 